\title{
Acidovorax anthurii sp. nov., a new phytopathogenic bacterium which causes bacterial leaf-spot of anthurium
}

\author{
L. Gardan, ${ }^{1}$ C. Dauga, ${ }^{2}$ P. Prior, ${ }^{3}$ M. Gillis ${ }^{4}$ and G. S. Saddler ${ }^{5}$ \\ Author for correspondence: L. Gardan. Tel: +3302412257 29. Fax: + 330241225705. \\ e-mail: gardan@angers.inra.fr
}

\footnotetext{
1 Institut National de la Recherche Agronomique, Station de Pathologie Végétale et de Phytobactériologie, Beaucouzé, France

2 Unité des Entérobactéries, INSERM U389, Institut Pasteur, Paris, France

3 Institut National de la Recherche Agronomique, Station de Pathologie Végétale, Montfavet, France

${ }^{4}$ Laboratorium Voor Microbiologie, Universiteit Gent, Ghent, Belgium

5 CABI Bioscience, Egham, UK
}

\begin{abstract}
The bacterial leaf-spot of anthurium emerged during the 1980s, in the French West Indies and Trinidad. This new bacterial disease is presently wide spread and constitutes a serious limiting factor for commercial anthurium production. Twenty-nine strains isolated from leaf-spots of naturally infected anthurium were characterized and compared with reference strains belonging to the Comamonadaceae family, the genera Ralstonia and Burkholderia, and representative fluorescent pseudomonads. From artificial inoculations 25 out of 29 strains were pathogenic on anthurium. Biochemical and physiological tests, fatty acid analysis, DNA-DNA hybridization, 16S rRNA gene sequence analysis, DNA-16S RNA hybridization were performed. The 25 pathogenic strains on anthurium were clustered in one phenon closely related to phytopathogenic strains of the genus Acidovorax. Anthurium strains were 79-99\% ( $\Delta T_{m}$ range 0.2-1.6) related to the strain CFBP 3232 and constituted a discrete DNA homology group indicating that they belong to the same species. DNA-rRNA hybridization, 16S rRNA sequence and fatty acid analysis confirmed that this new species belongs to the $\beta$-subclass of Proteobacteria and to rRNA superfamily III, to the family of Comamonadaceae and to the genus Acidovorax. The name Acidovorax anthurii is proposed for this new phytopathogenic bacterium. The type strain has been deposited in the Collection Française des Bactéries Phytopathogènes as CFBP $3232^{\top}$.
\end{abstract}

Keywords: Acidovorax anthurii, plant pathogen, rDNA sequencing, bacterial leafspot, DNA-DNA hybridization

\section{INTRODUCTION}

Anthurium andreanum Lind. is an important ornamental cash-crop found in most tropical-humid countries in the world and in particular the Caribbean, Latin America and Hawaii. Anthuriums have remained relatively disease free, however several bacterial, fungal and viral diseases may damage production without becoming a serious limiting factor for anthurium production (Chase, 1987). During the 1980s, hybrid and standard anthuriums, in Hawaii, Venezuela, Trinidad, the French West Indies, Philippines and Jamaica (Nishijima et al., 1980; Rott \& Prior, 1987; Natural, 1990; Young, 1990), were

Abbreviation: UPGMA, unweighted pair group method with averages. The EMBL accession number for the 16S rRNA gene sequence of Acidovorax anthurii strain CFBP $3232^{\top}$ is AJ007013. heavily infested by a vascular bacterial blight disease caused by Xanthomonas axonopodis pv. dieffenbachiae. However, a distinct bacterial disease, the bacterial leafspot, causing only limited damage compared to those due to bacterial blight, has emerged recently in some anthurium farms in the French West Indies and Trinidad (Prior \& Rott, 1987; Saddler et al., 1995). Following the first observations in restricted areas in Guadeloupe, bacterial leaf-spot was confirmed in Trinidad (Dilbar et al., 1992) and is becoming more widespread. It has been identified as a serious limiting factor for commercial anthurium production.

The new disease of anthurium is described as bacterial leaf-spot, because the first symptoms consist of necrotic lesions close to veins and leaf margins, which blacken and turn grey. From these lesions, bacteria enter the leaf and spathe parenchymas and become systemic, resulting in tissue discoloration and plant 
Table 1. Origin of the strains of Acidovorax, Burkholderia, Herbaspirillum and fluorescent and non-fluorescent Pseudomonas examined in this study

CFBP, Collection Française des Bactéries Phytopathogènes, Angers, France; ATCC, American Type Culture Collection, Manassas, VA, USA; ICMP, International Collection of Microorganisms from Plants, Auckland, New Zealand; IMI, International Mycological Institute, Egham, Surrey, UK; LMG, BCCM/LMG Bacteria Collection, Laboratorium voor Microbiologie Ghent, Belgium; NCIMB, National Collection of Industrial and Marine Bacteria, Aberdeen, UK; NCPPB, National Collection of Plant-Pathogenic Bacteria, Harpenden, UK.

\begin{tabular}{|c|c|c|c|}
\hline Name & $\begin{array}{l}\text { Strain no. as } \\
\text { received }\end{array}$ & $\begin{array}{c}\text { Other } \\
\text { designation }\end{array}$ & $\begin{array}{l}\text { Host plant or origin and place } \\
\text { and year of isolation }\end{array}$ \\
\hline Acidovorax anthurii & CFBP 3231 & & Anthurium sp. (hybrid.), Martinique, 1991 \\
\hline Acidovorax anthurii & CFBP $3232^{\mathrm{T}}$ & & Anthurium sp. (hybrid.), Martinique, 1991 \\
\hline Acidovorax anthurii & CFBP $3233 \mathrm{~A}^{*}$ & & Anthurium sp. (hybrid.), Martinique, 1991 \\
\hline Acidovorax anthurii & CFBP 3233 B* & & Anthurium sp. (hybrid.), Martinique, 1991 \\
\hline Acidovorax anthurii & CFBP 3234 A* $^{*}$ & & Anthurium sp. (hybrid.), Martinique, 1991 \\
\hline Acidovorax anthurii & CFBP 3234 B* & & Anthurium sp. (hybrid.), Martinique, 1991 \\
\hline Acidovorax anthurii & CFBP 3236 & & Anthurium sp. (hybrid.), Martinique, 1991 \\
\hline Acidovorax anthurii & CFBP 3237 & & Anthurium sp. (hybrid.), Martinique, 1991 \\
\hline Acidovorax anthurii & CFBP 3240 & & Anthurium sp. (hybrid.), Martinique, 1991 \\
\hline Acidovorax anthurii & CFBP 3241 & & Anthurium sp. (hybrid.), Martinique, 1991 \\
\hline Acidovorax anthurii & CFBP 3242 & & Anthurium sp. (hybrid.), Martinique, 1984 \\
\hline Acidovorax anthurii & CFBP 3243 & & Anthurium sp. (hybrid.), Martinique, 1984 \\
\hline Acidovorax anthurii & CFBP 3244 & & Anthurium sp. (hybrid.), Martinique, 1985 \\
\hline Acidovorax anthurii & CFBP 3245 & & Anthurium sp. (hybrid.), Martinique, 1984 \\
\hline Acidovorax anthurii & CFBP 3246 & & Anthurium sp. (hybrid.), Martinique, 1985 \\
\hline Acidovorax anthurii & CFBP 3247 & & Anthurium sp. (hybrid.), Martinique, 1985 \\
\hline Acidovorax anthurii & CFBP 3248 & & Anthurium sp. (hybrid.), Martinique, 1985 \\
\hline Acidovorax anthurii & CFBP 3249 & & Anthurium sp. (hybrid.), Martinique, 1985 \\
\hline Acidovorax anthurii & CFBP 3250 & & Anthurium sp. (hybrid.), Martinique, 1985 \\
\hline Acidovorax anthurii & CFBP 3251 & & Anthurium sp. (hybrid.), Martinique, 1985 \\
\hline Acidovorax anthurii & CFBP 3252 & & A. lanceolatum (hybrid.), Martinique, 1985 \\
\hline Acidovorax anthurii & CFBP 3282 & & Anthurium sp. (hybrid.), Martinique, 1985 \\
\hline Acidovorax anthurii & CFBP 10907 & & Anthurium sp. (hybrid.), Martinique, 1985 \\
\hline Acidovorax anthurii & CFBP 10908 & & Anthurium sp. (hybrid.), Martinique, 1985 \\
\hline Acidovorax anthurii & CFBP 10909 & & Anthurium sp. (hybrid.), Martinique, 1985 \\
\hline Acidovorax anthurii & CFBP 10910 & & Anthurium sp. (hybrid.), Martinique, 1985 \\
\hline Unknown & CFBP 3235 & & Anthurium sp. (hybrid.), Martinique, 1991 \\
\hline Unknown & CFBP 3238 & & Anthurium sp. (hybrid.), Martinique, 1991 \\
\hline Unknown & CFBP 3239 & & Anthurium sp. (hybrid.), Martinique, 1991 \\
\hline Unknown & CFBP 10908 & & Anthurium sp. (hybrid.), Martinique, 1985 \\
\hline $\begin{array}{l}\text { Acidovorax avenae subsp. avenae } \\
(=\text { Pseudomonas rubrilineans })\end{array}$ & NCPPB 920 & CFBP 1201 & Saccharum officinarum, Réunion, 1960 \\
\hline Acidovorax avenae subsp. avenae & NCPPB $1011^{\mathrm{T}}$ & CFBP $2425^{\mathrm{T}}$ & Zea mays, USA, 1961 \\
\hline Acidovorax avenae subsp. avenae & NCPPB 1392 & CFBP 2426 & Oryza sativa, Japan, 1963 \\
\hline Acidovorax avenae subsp. cattleyae & NCPPB $961^{\mathrm{T}}$ & CFBP $2423^{\mathrm{T}}$ & Host and place unknown, 1961 \\
\hline Acidovorax avenae subsp. citrulli & NCPPB $3679^{\mathrm{T}}$ & CFBP $10880^{\mathrm{T}}$ & Citrullus lanatus, USA, year unknown \\
\hline Acidovorax delafieldii & NCIMB $11476^{\mathrm{T}}$ & & \\
\hline Acidovorax facilis & NCIMB $9938^{\mathrm{T}}$ & & \\
\hline Acidovorax konjaci & NCPPB $3698^{\mathrm{T}}$ & CFBP $10881^{\mathrm{T}}$ & Amorphophalus konjac, Japan, year unknown \\
\hline Acidovorax sp. & CFBP 4692 & & Valerianella locusta, France, 1992 \\
\hline Acidovorax sp. & CFBP 4693 & & Valerianella locusta, France, 1992 \\
\hline Acidovorax sp. & CFBP 4694 & & Valerianella locusta, France, 1992 \\
\hline Acidovorax sp. & CFBP 4695 & & Valerianella locusta, France, 1992 \\
\hline Unknown & CFBP 4696 & & Valerianella locusta, France, 1992 \\
\hline Burkholderia caryophylli & NCPPB $2151^{\mathrm{T}}$ & CFBP $2429^{\mathrm{T}}$ & Dianthus caryophyllus, USA, 1951 \\
\hline Burkholderia plantarii & ICMP $9424^{\mathrm{T}}$ & CFBP $3199^{\mathrm{T}}$ & Oryza sativa, Japan, 1982 \\
\hline Burkholderia glumae & NCPPB $2391^{\mathrm{T}}$ & CFBP $2430^{\mathrm{T}}$ & Oryza sativa, Japan, 1967 \\
\hline
\end{tabular}


Table 1 (cont.)

\begin{tabular}{|c|c|c|c|}
\hline Name & $\begin{array}{l}\text { Strain no. as } \\
\text { received }\end{array}$ & $\begin{array}{c}\text { Other } \\
\text { designation }\end{array}$ & $\begin{array}{l}\text { Host plant or origin and place } \\
\text { and year of isolation }\end{array}$ \\
\hline Burkholderia cepacia & NCPPB $2993^{\mathrm{T}}$ & CFBP $2227^{\mathrm{T}}$ & Allium сера, USA, 1948 \\
\hline Burkholderia gladioli & IMI 347513 & & Gladiolus sp., Israël, 1958 \\
\hline Burkholderia gladioli pv. alliicola & NCPPB 947 & CFBP $2422^{\mathrm{T}}$ & Allium сера, USA, 1939 \\
\hline Burkholderia gladioli pv. gladioli & NCPPB $1891^{\mathrm{T}}$ & CFBP $2427^{\mathrm{T}}$ & Gladiolus sp., place unknown 1966 \\
\hline Burkholderia andropogonis & NCPPB $934^{\mathrm{T}}$ & CFBP $2421^{\mathrm{T}}$ & Sorghum officinale, USA, 1961 \\
\hline Delftia acidovorans & NCIMB $9681^{\mathrm{T}}$ & & \\
\hline Commamonas terrigena & NCIMB $8193^{\mathrm{T}}$ & & \\
\hline Commamonas testosteroni & NCIMB $8955^{\mathrm{T}}$ & & \\
\hline Herbaspirillum rubrisubalbicans & NCPPB $1026^{\mathrm{T}}$ & CFBP $1202^{\mathrm{T}}$ & Saccharum officinarum, Jamaica, 1961 \\
\hline Herbaspirillum rubrisubalbicans & IMI 347532 & & Saccharum officinarum, USA, 1961 \\
\hline Pseudomonas cissicola & NCPPB $2982^{\mathrm{T}}$ & CFBP $2432^{\mathrm{T}}$ & Cissus japonicus, Japan, 1974 \\
\hline Pseudomonas meliae & ICMP $6289^{\mathrm{T}}$ & CFBP $3225^{\mathrm{T}}$ & Melia azedarach, Japan, 1974 \\
\hline $\begin{array}{l}\text { Pseudomonas pseudoalcalignes subsp. } \\
\text { pseudoalcalignes }\end{array}$ & NCPPB $1971^{\mathrm{T}}$ & CFBP $2435^{\mathrm{T}}$ & Sinus drainage, France, 1956 \\
\hline Pseudomonas alcaligenes & ATCC $14909^{\mathrm{T}}$ & CFBP $2437^{\mathrm{T}}$ & Water, place unknown, 1961 \\
\hline Pseudomonas syzygii & NCPPB $3446^{\mathrm{T}}$ & CFBP $11053^{\mathrm{T}}$ & Syzygium aromaticum, Sumatra, 1980 \\
\hline Pseudomonas aeruginosa & ATCC $10145^{\mathrm{T}}$ & CFBP $2466^{\mathrm{T}}$ & Host, origin, place and year unknown \\
\hline Pseudomonas agarici & ICMP $2656^{\mathrm{T}}$ & CFBP $2063^{\mathrm{T}}$ & Agaricus bisporus, New Zealand, 1969 \\
\hline Pseudomonas asplenii & ICMP $3944^{T}$ & CFBP $3279^{\mathrm{T}}$ & Asplenium nidus, place unknown, 1966 \\
\hline Pseudomonas aureofaciens & ATCC $13985^{\mathrm{T}}$ & CFBP $2133^{\mathrm{T}}$ & Host, origin, place and year unknown \\
\hline 'Pseudomonas blatchfordae' & ICMP 8933 & CFBP 3280 & Phaseolus vulgaris, USA, 1980 \\
\hline Pseudomonas caricapapayae & NCPPB $1873^{\mathrm{T}}$ & CFBP $3204^{T}$ & Carica papaya, Brazil, 1966 \\
\hline Pseudomonas chlororaphis & ATCC $9446^{\mathrm{T}}$ & CFBP $2132^{\mathrm{T}}$ & Plate contaminant, place and year unknown \\
\hline Pseudomonas cichorii & NCPPB $943^{\mathrm{T}}$ & CFBP $2101^{\mathrm{T}}$ & Cichorium endivia, Germany, 1929 \\
\hline Pseudomonas cichorii & NCPPB 906 & & Chrysantemum morifolium, USA, 1957 \\
\hline Pseudomonas flectens & ICMP $745^{\mathrm{T}}$ & CFBP $3281^{\mathrm{T}}$ & Phaseolus vulgaris, Australia, 1956 \\
\hline Pseudomonas fluorescens biotype A & ATCC $13525^{\mathrm{T}}$ & CFBP $2102^{\mathrm{T}}$ & Water, UK, 1951 \\
\hline Pseudomonas fuscovaginae & CFBP $2065^{\mathrm{T}}$ & NCPPB 3085 & Oryza sativa, Japan, 1976 \\
\hline Pseudomonas marginalis pv. alfalfae & NCPPB 2644 & CFBP 2039 & Medicago sativa, USA, 1971 \\
\hline Pseudomonas marginalis pv. marginalis & CFBP $3300^{T}$ & LMG $2210^{\mathrm{T}}$ & Cichorium intybus, USA, 1949 \\
\hline Pseudomonas marginalis pv. pastinacae & CFBP $2038^{\mathrm{T}}$ & NCPPB 806 & Pastinaca sativa, USA, 1959 \\
\hline Pseudomonas putida biotype A & CFBP $2066^{\mathrm{T}}$ & ATCC $12633^{\mathrm{T}}$ & Soil, USA, year unknown \\
\hline Pseudomonas sp. & CFBP 2022 & & Allium sativum, France, 1976 \\
\hline Pseudomonas stutzeri & ATCC 17588 & CFBP 2443 & Spinal fluid, USA, 1970 \\
\hline Pseudomonas syringae pv. atrofaciens & NCPPB 2612 & & Triticum aestivum, Zimbabwe, 1973 \\
\hline Pseudomonas syringae pv. delphinii & NCPPB 2666 & CFBP 1641 & Delphinium sp., UK, 1974 \\
\hline Pseudomonas syringae pv. helianthi & NCPPB 1229 & & Helianthus annuus, Zambia, 1962 \\
\hline Pseudomonas syringae pv. morsprunorum & IMI 349210 & & Prunus domestica, UK, 1967 \\
\hline Pseudomonas syringae pv. pisi & NCPPB 123 & & Host unknown, Australia, 1938 \\
\hline Pseudomonas syringae pv. syringae & CFBP 1542 & NCPPB 2784 & Euonymus japonicus, France, 1974 \\
\hline Pseudomonas syringae pv. tabaci & NCPPB 214 & & Nicotiana tabaccum, Zimbabwe, 1948 \\
\hline Pseudomonas tolaasii & CFBP $2068^{\mathrm{T}}$ & NCPPB $2192^{\mathrm{T}}$ & Agaricus bisporus, UK, 1965 \\
\hline Pseudomonas tolaasii & CFBP 2810 & NCPPB 3146 & Agaricus bisporus, UK, 1981 \\
\hline Ralstonia solanacearum & CFBP $2047^{\mathrm{T}}$ & NCPPB $325^{\mathrm{T}}$ & Lycopersicum esculentum, USA, 1953 \\
\hline Ralstonia solanacearum & & IMI 347554 & Solanum tuberosum, Egypt, 1959 \\
\hline
\end{tabular}

* A and B represent two different clones of the strain.

death. Prior \& Rott (1989) have shown by biochemical characteristics that bacterial leaf-spot symptoms of anthurium were associated with an undescribed Pseudomonas sp. related to the previous large group of non-fluorescent pseudomonads now assigned to the
Comamonadaceae, and the genera Ralstonia, Burkholderia and Herbaspirillum (Kersters et al., 1996). Moreover they showed that this bacterium differs from other previously described phytopathogenic bacteria. Saddler et al. (1995) confirmed 
the characterization of this bacterium, and suggested a similarity with the genus Acidovorax, using fatty acid profile and PCR-RAPD analyses.

Because of the incomplete description of this bacterium, and some uncertainty about its phylogeny, the present study was initiated to produce a full description based on phenotypic and physiological tests, fatty acids, DNA-DNA and DNA-rRNA hybridization analyses and 16S rRNA sequence analysis. Our results indicate clearly that the bacterium is a new phytopathogenic bacterium within the genus Acidovorax, and for which the name Acidovorax anthurii has been proposed.

\section{METHODS}

Bacteria. The data detailed below are based on a collection of 29 isolates from naturally infected Anthurium lanceolatum L. and hybrid anthuriums from Martinique (Table 1). The strains were isolated from leaf-spots and vascular necrosis of petioles and spathes on YBGA $(0.7 \%$ yeast extract; $0.7 \%$ bactopeptone; $0.7 \%$ glucose and $1.5 \%$ agar; $\mathrm{pH} 7 \cdot 3$ ). White-grey colonies evident on agar plates after $48 \mathrm{~h}$ reach a diameter of $1.5-2.0 \mathrm{~mm}$. The cultures were preserved either by freeze-drying or on agar slopes under oil at $4{ }^{\circ} \mathrm{C}$. In addition, reference strains from a variety of culture collections were also included in this study (Table 1).

Pathogenicity tests. Inocula were prepared by suspending 24-h-old bacterial growth from slants in sterile distilled water and adjusting the cell density to $5 \times 10^{8}$ c.f.u. $\mathrm{ml}^{-1}$. Inoculation tests were made with all 29 isolates listed in Table 1 on both the leaf and spathe lamina by infiltration of a bacterial suspension in the mesophyll near the vein of leaves and spathes lamina of hybrid anthurium. Sterile distilled water was used as control. The inoculated plants were incubated for 6 weeks in a closed humid chamber in a greenhouse under a relative humidity of $90 \%$ and a mean temperature of $26^{\circ} \mathrm{C}$.

Biochemical and physiological tests. The presence of flagella was confirmed by the method of Rhodes (1958). Oxidationfermentation of glucose was performed by the method of Hugh \& Leifson (1953). Growth at 37 and $41^{\circ} \mathrm{C}$ was observed using liquid nitrate medium and recorded after $5 \mathrm{~d}$ incubation. The presence of oxidase, gelatinase and arginine dihydrolase activities, fluorescent pigment on agar medium King's B, levan formation, acid production from sucrose, sorbitol, erythritol and mannitol, reduction of nitrates, hydrolysis of Tween 80 and aesculin and the hypersensitivity reaction on tobacco leaves were tested as described by Leliott et al. (1966). Pectinolytic activity was tested using the method of Prunier \& Kaiser (1964) and Hildebrand (1971). Utilization of lactate $\mathrm{L}(+)$ tartrate and $\mathrm{D}(-)$ tartrate was tested on the basal medium of Ayers et al. (1919) supplemented with $0 \cdot 1 \%(\mathrm{w} / \mathrm{v})$ organic acid sodium salts. The presence of DNase was tested on DNA agar (Diagnostic Pasteur). Assimilation of 49 carbohydrates, 49 organic acids and 49 amino acids were studied using API 50CH, API 50AO and API 50AA strips (bioMérieux). The accumulation of granules of PHB was observed by the method of Ostle \& Holt (1975) using Nile blue A. Ralstonia solanacearum CFBP $2047^{\mathrm{T}}$ was used as a positive control.

Numerical taxonomy. A total of 167 characters was included in the numerical taxonomic analysis. The distance matrix was calculated using the Jaccard coefficient (Sneath \& Sokal, 1973). Cluster analysis was achived using unweighted pair group method with averages (UPGMA) (Sneath \& Sokal, 1973).

At a given distance level and for the different phena, the amount of information for each test was measured by calculating the diagnostic capacity coefficient (DCC) (Descamps \& Veron, 1981) to determine discriminating biochemical characteristics.

DNA extraction. Extraction and purification of DNA were performed using previously described methods (Brenner et al., 1982). The strains studied are listed in Table 3.

DNA-DNA hybridization. Native DNAs were labelled in vitro by nick translation with tritium-labelled nucleotides (Amersham International). The S1 nuclease-trichloracetic acid hybridization method was used as previously described (Crosa et al., 1973). The reassociation temperature was $70{ }^{\circ} \mathrm{C}$. DNA-DNA hybridization tests were carried out using labelled DNA from one strain CFBP $3232^{\mathrm{T}}$ isolated from anthurium. DNA-DNA hybridization tests were repeated at least twice.

Thermal stability of DNA reassociation. The temperature at which $50 \%$ of reassociated DNA became hydrolysable by nuclease $\mathrm{S} 1\left(T_{\mathrm{m}}\right)$ was determined using the method of Crosa et al. (1973). The $T_{\mathrm{m}}$ values were determined only if the percentage of DNA-DNA hybridization was between 65 and $70 \%$.

16S rRNA gene sequencing analysis. 16S rRNA gene (rDNA) fragments were amplified by PCR as previously described (Dauga, 1993). Primers including deoxy-UMP residues at the $5^{\prime}$ end were designed to amplify a 1500 base fragment of $16 \mathrm{~S}$ rDNA. The amplified product was purified using a Jet Pure system (Genomed), then cloned in Escherichia coli MC1061 with pAMP1 plasmid from the Cloneamp system (Gibco-BRL). Three clones were sequenced using $\left[\gamma_{-}{ }^{33} \mathrm{P}\right]-$ labelled dATP and Hot-Tub polymerase (Amersham International) by cycle sequencing (Blakesley, 1993).

16S rRNA gene sequence analysis. The sequences of the organisms used for alignment and the similarity matrix were obtained from GenBank/EMBL through DNASTAR. The reference sequences were also taken from the Ribosomal Database Project (Maidak et al., 1997) and the rRNA WWW server of the University of Antwerp (Belgium) (Van de Peer et al., 1994). The sequences being compared were aligned manually.

Distance analyses were performed using the PHYLIP package in the DNADIST program (Felsenstein, 1989). Divergence between two sequences was estimated using the following formula: $K_{\text {nuc }}=-1 / 2 \ln \left[(1-2 \mathrm{P}-\mathrm{Q})(1-2 \mathrm{Q})^{1 / 2}\right]($ Kimura, 1980). A phylogenetic tree was constructed by the neighbourjoining method (Saitou \& Nei, 1987). Parsimony analysis was performed with the PAUP program using the heuritic option (Swofford, 1990). The robustness of each topology was evaluated under the two methods described through 100 bootstrap replications. A maximum-likelihood analysis was also done with fastDNAml (Felsenstein, 1981; Olsen et al., 1994).

Nucleotide sequence accession numbers. The EMBL/ GenBank accession numbers of the 16S rRNA sequences used in the phylogenetic analyses were as follows: Burkholderia cepacia ATCC 25416 ${ }^{\mathrm{T}}$, M22518 and M22467; Burkholderia sp. GSY, U16140; Burkholderia sp. 2 K172, X77118; Burkholderia sp. 3 KB740, X77679; Burkholderia 

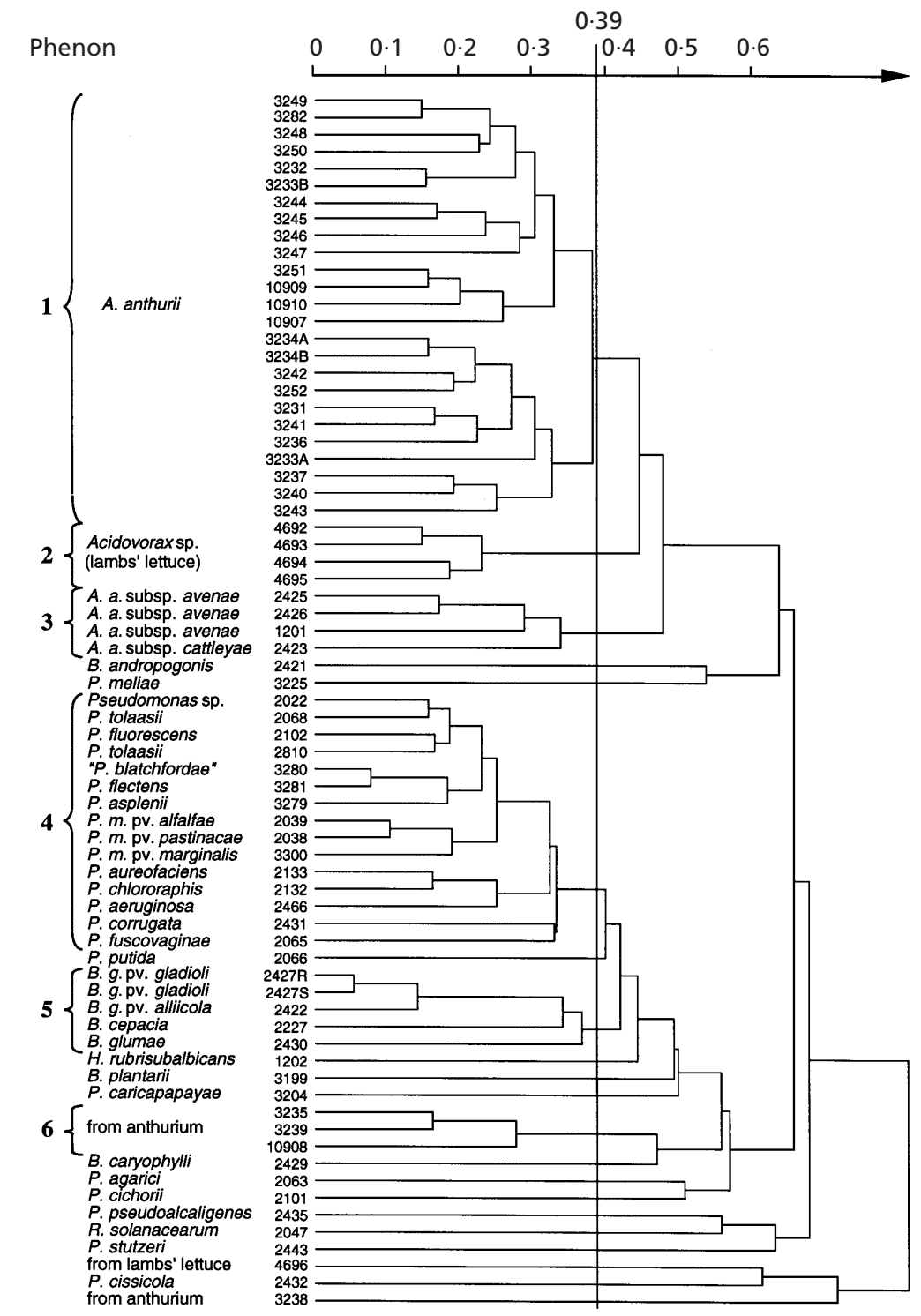

Fig. 1. Dendrogram of the distances among the 71 strains studied.

andropogonis ATCC 23061, X67037; Ralstonia solanacearum biovar 2 ACM 158, X67035; Ralstonia solanacearum biovar 3 ATCC 11696 ${ }^{\mathrm{T}}$, X67036; Ralstonia solanacearum biovar 4 ACH 092, X67040; Ralstonia solanacearum biovar 5 ACH 0171, X67041; Ralstonia pickettii ATCC 27511 ${ }^{\mathrm{T}}$, S55004; Telluria chitinolytica sb. 2 K172, X65590; Telluria mixta str. ACM17, X65589; Acidovorax facilis DSM 649 ${ }^{\mathrm{T}}$, X59169; Variovorax paradoxus IAM 12373, D30793; Comamonas testosteroni ATCC 11996, M11224; Delftia acidovorans DSM 39 ${ }^{\mathrm{T}}$, X59168; Pseudomonas putida $\mathrm{mt} 2$, L28676; Pseudomonas mendocina ATCC 25411, M59154; Pseudomonas aeruginosa ATCC 10145 ${ }^{\mathrm{T}}$, X06684; Brevundimonas diminuta ATCC 11568, M59064; Halomonas halophila DSM 4770, M93353; Halomonas marina ATCC 25374, M93354; Halomonas aquamarina ATCC 14400, M93352; Stenotrophomonas maltophilia ATCC 13637, M59158.

DNA base composition. To determine the $\mathrm{G}+\mathrm{C}$ content, purifed DNA was diluted in $0 \cdot 1 \times \mathrm{SCC}$ buffer at a final concentration of $50 \mu \mathrm{g} \mathrm{ml}^{-1}$. The $\mathrm{G}+\mathrm{C}$ content was determined by the thermal denaturation temperature (Marmur
$\&$ Doty, 1962) and was calculated using the equation of Owen \& Lapage (1976). The DNA from $P$. corrugata CFBP $2431^{\mathrm{T}}(\mathrm{G}+\mathrm{C}$ content $60 \mathrm{~mol} \%)$ was used as a standard.

DNA-rRNA hybridization. The hybridization method of De Ley \& De Smedt (1975) was used. Each rRNA-DNA hybrid was characterized by its $T_{m}(\mathrm{e})$ (the temperature at which $50 \%$ of rRNA-DNA hybrid was denatured). Labelled $\left({ }^{3} \mathrm{H}\right)$ rRNA from Acidovorax avenae subsp. avenae NCPPB $1011^{\mathrm{T}}$ was used.

Fatty acid extraction and analysis. Biomass was prepared by harvesting cultures grown on Trypticase Soy Broth Agar (TSBA) for $48 \mathrm{~h}$ at $28^{\circ} \mathrm{C}$ as described previously (Sasser, 1990). Fatty acids were extracted and derivatised using the method of Miller \& Berger (1985). The resultant fatty acid methyl esters were analysed by GC (Hewlett Packard 5890) in conjunction with the Microbial Identification System (MIDI). Each fatty acid profile was repeated six times, with a fresh cultivation/extraction conducted on each occasion. The mean profile of strains were clustered using the UPGMA 
protocol from Euclidean distance measurements using software from MVSP (Anglesey, UK).

\section{RESULTS}

\section{Pathogenicity}

The pathogenicity of 25 out of 29 strains studied was confirmed using anthurium plants. Three to five days after inoculation, tissues appeared brown to black. Subsequently the margin of the necrotic lesion became watersoaked. After more than $10 \mathrm{~d}$, the development of the disease was halted and the necrotic lesions were surrounded by a typical bright yellow halo. At the same time the vascular development of the disease was observed resulting in abscission of leaf and spathe petioles. After 4 weeks incubation we observed typical symptoms on leaves and spathes which had not been artificially inoculated. The bacteria were easily reisolated in pure culture especially from watersoaked tissues, thoughout the incubation period. Strains CFBP 3235, 3239, 10908 and 3238 did not induce any symptoms.

The pathogenic strains isolated from anthurium displayed characteristics common to the genus Acidovorax: straight rods, $0.2-0.7 \times 1.0-5.0 \mu \mathrm{m}$, occurring

Table 2. Characteristics that differentiate Acidovorax anthurii from other Acidovorax species and other plantpathogenic species: Pseudomonas, Herbaspirillum, Burkholderia and Ralstonia tested

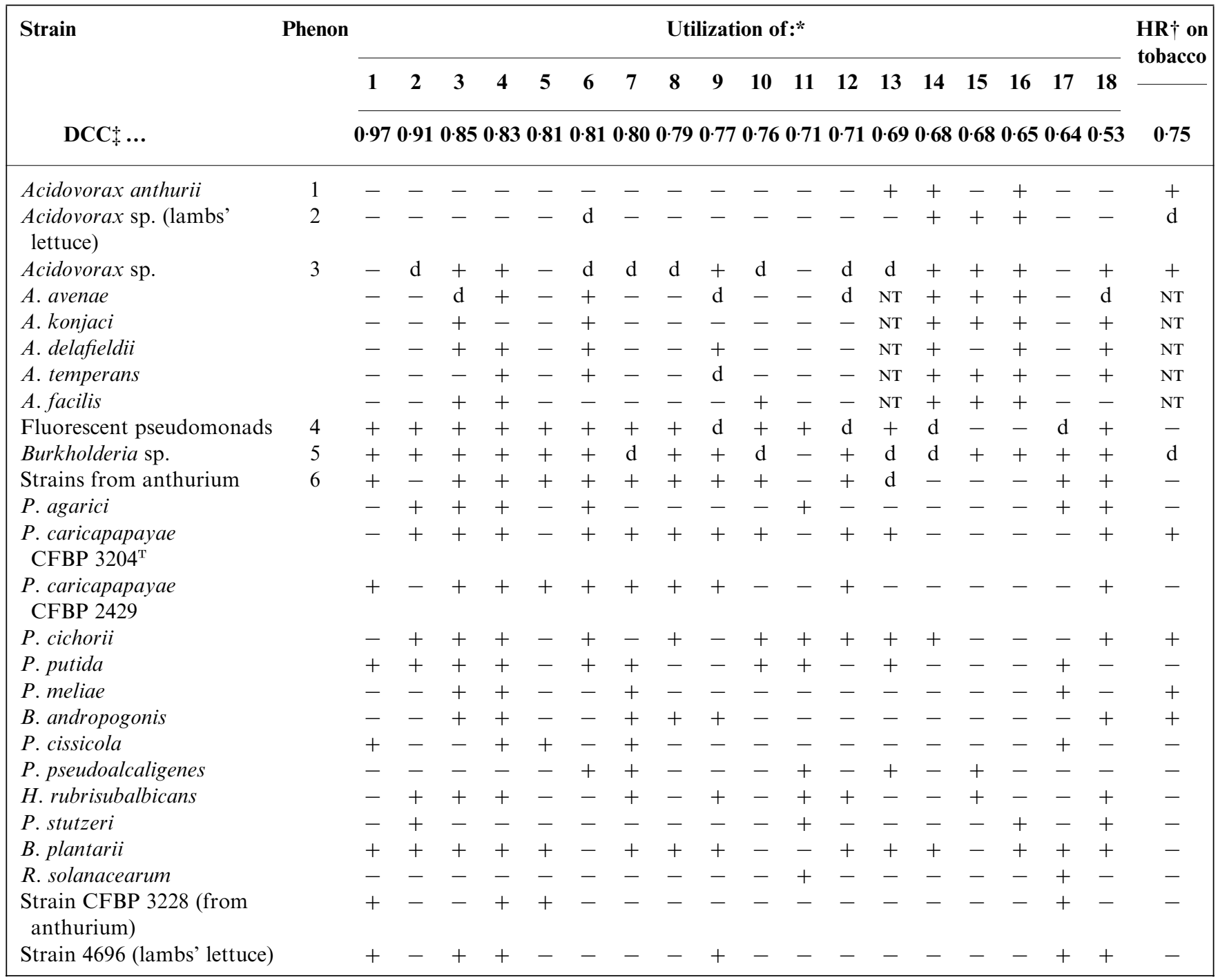

NT, Not tested.

* Numbers represent: 1 , trehalose; 2, caprylate; 3, D-ribose; 4, D-glucose; 5, $N$-acetylglucosamine; 6, L-arginine; 7, saccharose; 8 , inositol; 9, sorbitol; 10, sarcosine; 11, itaconate; 12, D-xylose; 13, DL-5-aminobutyrate; 14, D(-)tartrate; 15, L-trytophan; 16, azelate; 17, aesculin; 18, mannitol.

$\uparrow \mathrm{HR}$, Hypersensitive reaction.

† DCC, Diagnostic Capacity Coefficient. 
Table 3. Levels of DNA relatedness among A. anthurii, Acidovorax avenae and A. konjaci, Burkholderia and plant-pathogenic Pseudomonas strains

Relative binding $(\%)$ at $70{ }^{\circ} \mathrm{C}$ with labelled DNA from $A$. anthurii CFBP $3232^{\mathrm{T}}$.

\begin{tabular}{|c|c|c|c|}
\hline Taxon & $\begin{array}{c}\text { CFBP } \\
\text { no. }\end{array}$ & $\begin{array}{c}\text { Rel. binding to } \\
\text { CFBP 3232 } \\
\text { DNA (\%) }\end{array}$ & $\Delta T_{\mathrm{m}}\left({ }^{\circ} \mathrm{C}\right)$ \\
\hline A. anthurii & $3232^{\mathrm{T}}$ & 100 & $0 \cdot 1$ \\
\hline A. anthurii & 3237 & $96(5 \cdot 7)$ & $0 \cdot 9$ \\
\hline A. anthurii & 3244 & $99(4)$ & $0 \cdot 2$ \\
\hline A. anthurii & 3248 & $85(9)$ & $0 \cdot 9$ \\
\hline A. anthurii & 3249 & $86(7 \cdot 8)$ & $1 \cdot 6$ \\
\hline A. anthurii & 3250 & $86(10 \cdot 5)$ & $0 \cdot 3$ \\
\hline A. anthurii & 3282 & $84(6 \cdot 4)$ & $1 \cdot 0$ \\
\hline A. anthurii & 10910 & $79(3 \cdot 2)$ & $0 \cdot 9$ \\
\hline A. anthurii & 3239 & 3 & \\
\hline A. avenae subsp. avenae & 1201 & 34 & \\
\hline A. avenae subsp. avenae & 2425 & 34 & \\
\hline A. avenae subsp. cattleyae & 2423 & 37 & \\
\hline A. avenae subsp. citrulli & 10880 & 34 & \\
\hline A. konjaci & 10881 & 44 & \\
\hline Acidovorax sp. (lambs' lettuce) & 4694 & 27 & \\
\hline R. solanacearum & 2047 & 7 & \\
\hline B. cepacia & 2027 & 7 & \\
\hline B. gladioli pv. alliicola & 2422 & 7 & \\
\hline B. gladioli pv. gladioli & 2427 & 8 & \\
\hline B. caryophylli & 2429 & 3 & \\
\hline B. glumae & 2430 & 5 & \\
\hline B. plantarii & 3199 & 8 & \\
\hline B. andropogonis & 2421 & 3 & \\
\hline H. rubrisubalbicans & 1202 & 6 & \\
\hline P. cissicola & 2432 & 3 & \\
\hline $\begin{array}{l}\text { P. pseudoalcaligenes subsp. } \\
\text { pseudoalcaligenes }\end{array}$ & 2435 & 3 & \\
\hline P. alcaligenes & 2437 & 0 & \\
\hline P. syzygii & 11053 & 4 & \\
\hline P. meliae & 3225 & 1 & \\
\hline P. aeruginosa & 2466 & 0 & \\
\hline P. agarici & 2063 & 0 & \\
\hline P. asplenii & 3279 & 0 & \\
\hline P. aureofaciens & 2133 & 3 & \\
\hline 'P. blatchfordae' & 3280 & 1 & \\
\hline P. caricapapayae & 3204 & 1 & \\
\hline P. chlororaphis & 2132 & 1 & \\
\hline P. cichorii & 2101 & 0 & \\
\hline P. flectens & 3281 & 0 & \\
\hline P. fuscovaginae & 2065 & 0 & \\
\hline P. fluorescens & 2102 & 0 & \\
\hline Pseudomonas sp. & 2022 & 0 & \\
\hline P. marginalis pv. marginalis & 1387 & 1 & \\
\hline P. marginalis pv. pastinacae & 2038 & 4 & \\
\hline P. tolaasii & 2068 & 1 & \\
\hline P. tolaasii & 2810 & 0 & \\
\hline P. putida & 2066 & 0 & \\
\hline
\end{tabular}

* Values in parentheses are standard deviation. 
Table 4. $T_{\mathrm{m}}(\mathrm{e})$ values of hybrids between DNAs from Acidovorax anthurii CFBP 3240 and $3232^{\top}$ and labelled rRNA from $A$. avenae subsp. avenae NCPPB $1011^{\top}$

\begin{tabular}{|lcc|}
\hline DNA from strain: & $\begin{array}{l}T_{\mathrm{m}}(\mathrm{e})\left({ }^{\circ} \mathrm{C}\right) \text { vs }\left[{ }^{3} \mathrm{H} \mid \mathrm{rRNA}\right. \\
\text { from } \text { A. avenae subsp. } \\
\text { avenae } \text { NCPPB } \text { 1011 }^{\mathrm{T}}\end{array}$ & $\boldsymbol{\Delta T _ { \mathrm { m } } ( \mathrm { e } )}$ \\
\hline $\begin{array}{l}\text { A. avenae subsp. avenae } \\
\text { NCPPB 1011 }\end{array}$ & $78 \cdot 8$ & 0 \\
A. konjaci ICMP 7851 & $75 \cdot 7$ & $3 \cdot 1$ \\
A. anthurii CFBP 3240 & $78 \cdot 4$ & $0 \cdot 4$ \\
A. anthurii CFBP 3232 & $77 \cdot 2$ & $1 \cdot 6$ \\
\hline
\end{tabular}
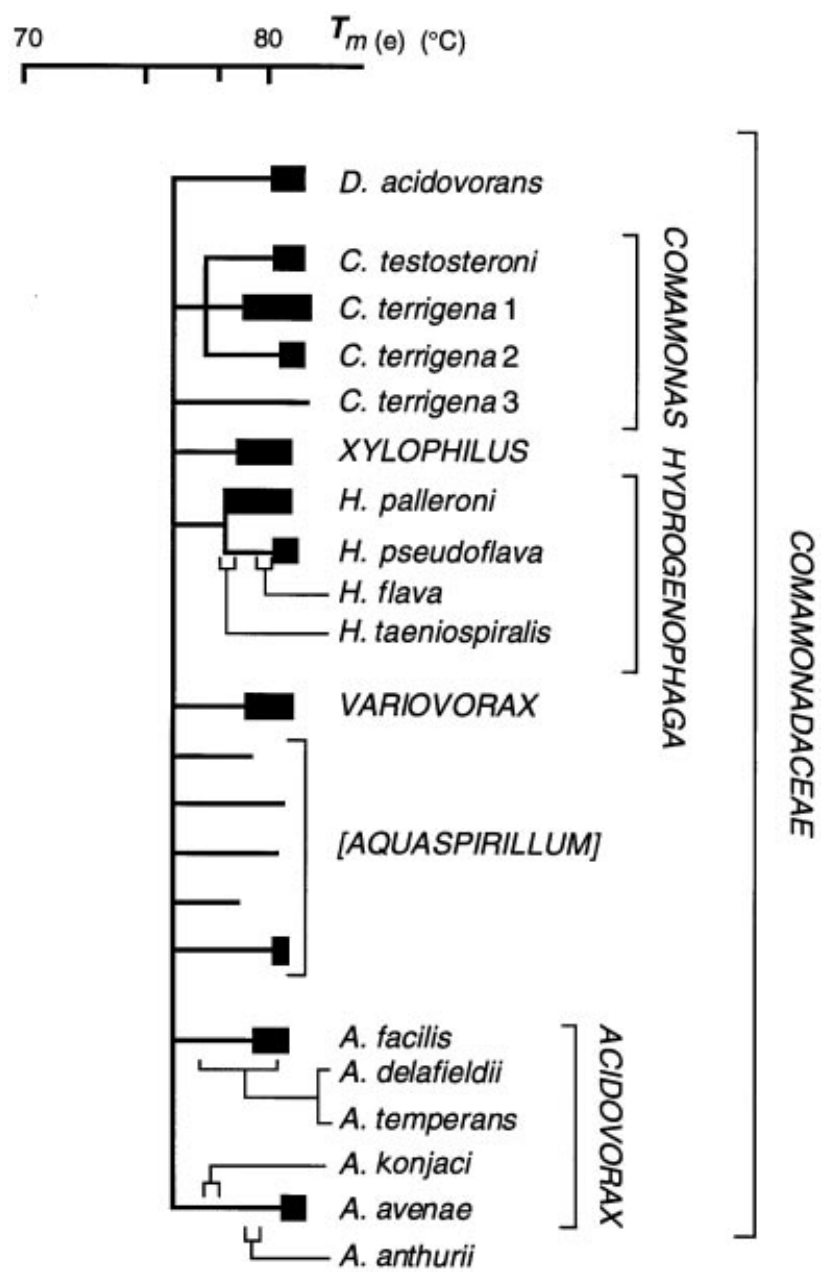

Fig. 2. rRNA cistron similarity dendrogram of Acidovorax anthurii within the Comamonadaceae, based on $T_{m}(\mathrm{e})$ values (in $\left.{ }^{\circ} \mathrm{C}\right)$ of DNA-rRNA hybrids.

mostly singly, motile by long polar flagella, Gramnegative, oxidase-positive, urease-positive, strictly aerobic, poly- $\beta$-hydroxybutyrate is accumulated intracellulary. Colonies were circular, raised with an entire margin and white-creamy on medium King's B and YPGA. No fluorescent pigment was produced on medium King's B but a brown diffusible pigment is generally produced when grown on YBGA. All isolates elicited a hypersensitive reaction on tobacco leaves $\mathrm{cv}$. samsun.

\section{Numerical analysis}

The dendrogram displaying the distance relationships amongst the 71 strains, studied is shown in Fig. 1. At the distance $0 \cdot 39$, six phena and 15 isolated strains can be distinguished. The distribution of species and pathovars in the six phena and isolated strains is shown in Table 2 . Phenon 1 contained 25 out of the 29 of the strains isolated from anthurium. Phenon 2 included four out of the five strains of Acidovorax sp. isolated from a necrosis on lambs' lettuce, the fifth strain, CFBP 4696 demonstrated a separate phenotype. Phenon 3 encompasses four strains of Acidovorax avenae and the type strain of $A$. avenae subsp. cattleyae, CFBP 2423. Phenon 4 includes 15 type strains of fluorescent and non-fluorescent Pseudomonas spp. belonging to the genus Pseudomonas sensu stricto. Phenon 5 includes strains of three Burkholderia spp. Phenon 6 contains three non-pathogenic strains isolated from necrotic lesions of anthurium whose identity is not known. Fifteen strains did not cluster at the distance of $0 \cdot 39$. Among these strains are 11 type strains of fluorescent and non-fluorescent Pseudomonas spp., two type strains of Burkholderia, $B$. andropogonis, B. plantarii and two unidentified strains, one isolated from anthurium and the other isolated from lambs' lettuce (Fig. 1).

Using the Diagnostic Capacity Coefficent (DCC) we selected 19 biochemical and physiological tests that differentiated the strains clustered in the different phena or isolated type strains (Table 2). A. anthurii could be distinguished from Acidovorax sp. (lambs' lettuce) and reference strains of Acidovorax of phenon 3 by two and five tests, respectively (Table 2). The differentiation between $A$. anthurii and strains of fluorescent Pseudomonas (phenon 4), Burkholderia (phenon 5) and other isolates from anthurium is possible by a range of biochemical tests (Table 2). This was also true for the rest of the strains tested here (Table 2).

\section{DNA-DNA hybridization}

Results of DNA hybridization studies are shown in Table 3. Nine representative $A$. anthurii strains from phenon 1 are $79-100 \%$ similar to the strain CFBP $3232^{\mathrm{T}}$. The $\Delta T_{\mathrm{m}}$ values ranged from $0 \cdot 1$ to $1 \cdot 6^{\circ} \mathrm{C}$. Strain CFBP 3239 from phenon 6, isolated from anthurium hybridized only $3.0 \%$ with the pathogenic strain CFBP $3232^{\mathrm{T}}$.

Representative strains of the three subspecies of Acidovorax avenae, Acidovorax konjaci, Acidovorax sp. CFBP 4694 were $27-44 \%$ related to $A$. anthurii CFBP $3232^{\mathrm{T}}$. Seven species of Burkholderia and seven species of non-fluorescent Pseudomonas were related only $0-8 \%$ to strain CFBP $3232^{\mathrm{T}}$. All strains of 


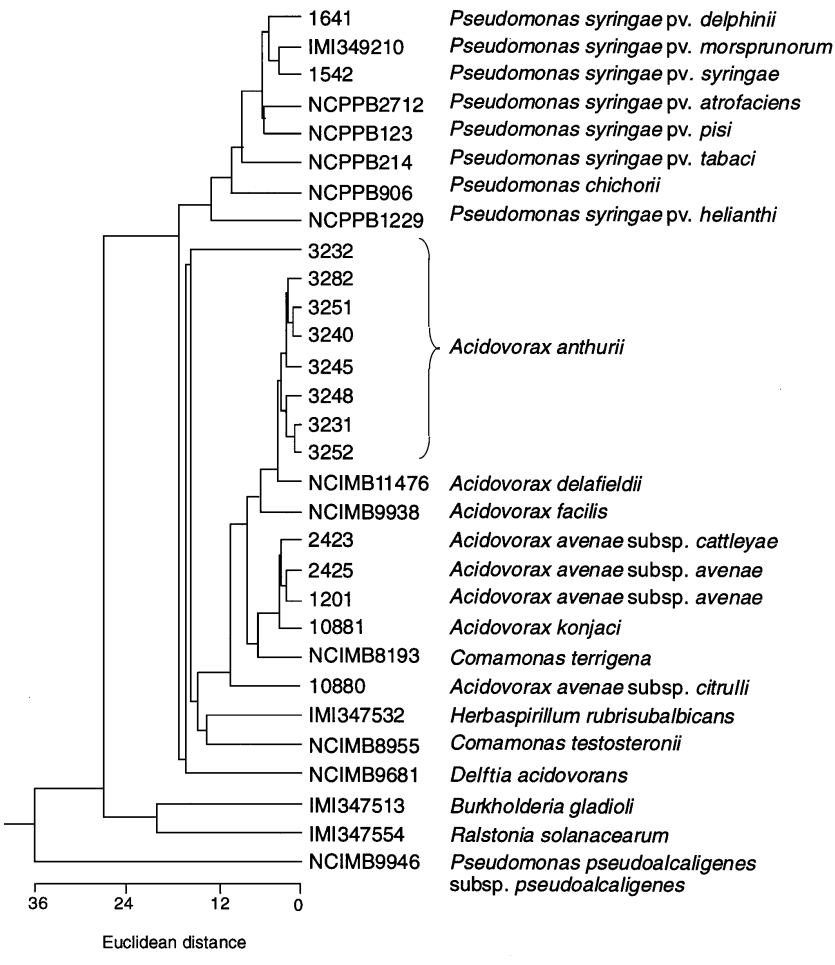

Fig. 3. Phylogenic tree obtained with the maximum likehood analysis (fastDNAml) showing the clustering of Acidovorax anthurii and Acidovorax facilis.

fluorescent Pseudomonas spp. included were distantly related $(0-4 \%)$ to strain CFBP $3232^{\mathrm{T}}$.

\section{DNA base composition}

The DNA $\mathrm{G}+\mathrm{C}$ base composition of strain CFBP $3232^{\mathrm{T}}$ was found to be $63.5 \mathrm{~mol} \%$.

\section{DNA-rRNA hybridization}

To verify the assigment of $A$. anthurii to the branch of A. avenae within the family Comamonadaceae, DNA from $A$. anthurii CFBP $3232^{\mathrm{T}}$ and 3240 and one strain of $A$. konjaci ICMP 7851 were hybridized with labelled rRNA of $A$. avenae subsp. avenae NCPPB $1011^{\mathrm{T}}$. The results are shown in Table 4.

Two strains CFBP $3232^{\mathrm{T}}$ and 3240 belonged to the Acidovorax rRNA branch and are thus members of the genus Acidovorax. Because of $\Delta T_{\mathrm{m}}(\mathrm{e})$ values of $0 \cdot 4-1 \cdot 6{ }^{\circ} \mathrm{C}$, this new species is more closely related to $A$. avenae subsp. avenae than to $A$. konjaci (Fig. 2). We could position $A$. anthurii within the family Comamonadaceae and the genus Acidovorax (Fig. 2).

\section{S rRNA gene sequence analysis}

The sequence of 1487 nucleotides of $16 \mathrm{~S}$ rDNA was determined, corresponding to positions 8-1509 in the E. coli numbering system (Brosius et al., 1978). Alignment of the sequence with related members of the

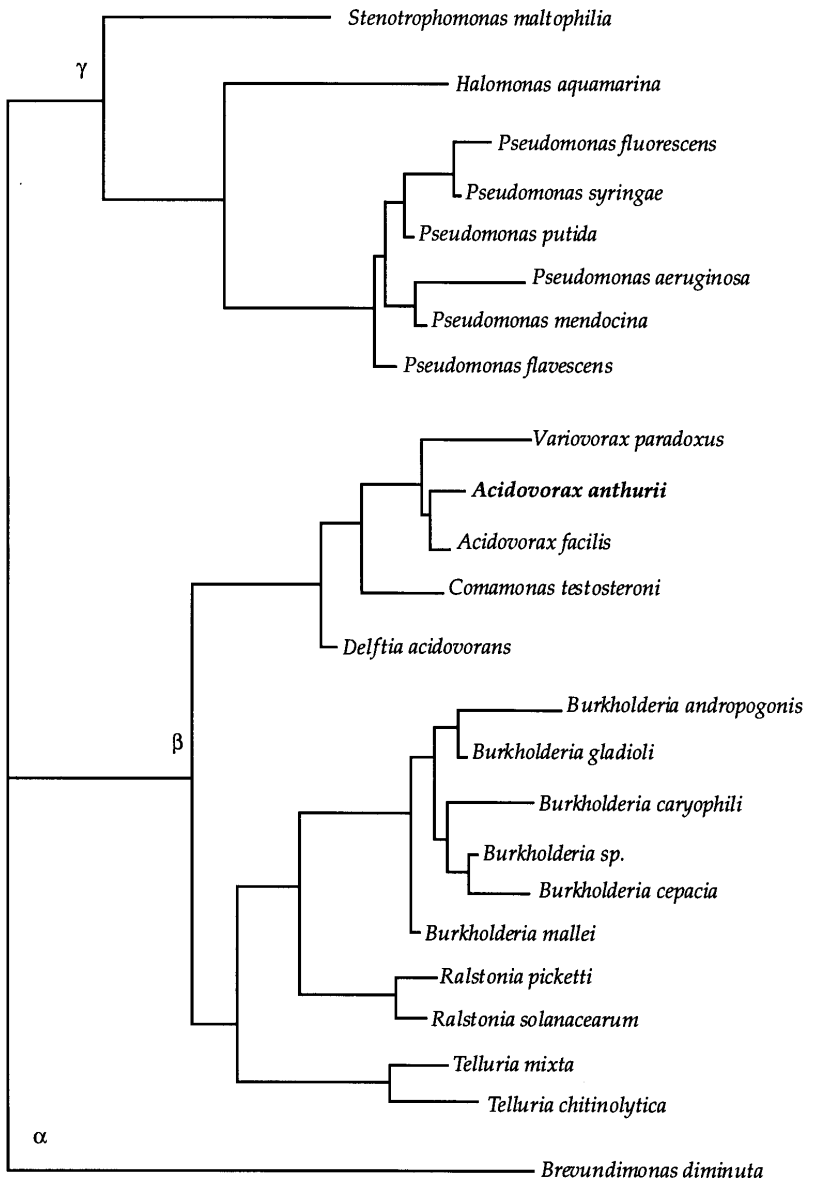

Fig. 4. Dendrogram of mean fatty acid profiles from strains of Acidovorax anthurii and reference strains from the families Comamonadaceae, Burkholderiaceae and Pseudomonadaceae, as calculated from Euclidean distance with clustering achieved by UPGMA.

$\beta$ subclass of the Proteobacteria reveals common signatures at positions 50, 812, 955, 976, 1233 and 1234 (Woese, 1987).

The phylogenetic tree obtained with the maximumlikelihood method is shown in Fig. 4. The overall phylogenetic structure obtained fits with known information on the Pseudomonadaceae (Kersters et al., 1996). Members of the rRNA group I, considered to contain the authentic genus Pseudomonas are in the $\gamma$ subclass of the Proteobacteria. Members of the rRNA group II and III, the pathogens or opportunistic pathogens of animals and plants are in the $\beta$ subclass of the Proteobacteria (De Vos et al., 1985). Our strain branched in the vicinity of Acidovorax facilis, Variovorax paradoxus, Delftia acidovorans and Comamonas testosteroni, which represent the Comamonadaceae. Clustering of these four species with $A$. anthurii was also observed in the phylogenetic tree obtained with the parsimony method and the neighbour-joining method (data not shown) done only on partial sequences because long stretches of rRNA sequences were not available for $C$. acidovorans and 
Table 5. Fatty acid profiles for the type strains of the genus Acidovorax

Data are mean percentage compositions, with standard deviations in parentheses. Species: 1 , A. anthurii CFBP $3232^{\mathrm{T}} ; 2, A$. anthurii; 3, A. a. subsp. avenae (= P. rubrilineans) CFBP $1201 ; 4$, A avenae subsp. avenae CFBP $2425 ; 5, A$. avenae subsp. cattleyae CFBP 2423; 6, A. avenae subsp. citrulli CFBP 10880; 7, A. delafieldii NCIMB 11476; 8, A. facilis NCIMB 9938; 9, A. konjaci CFBP 10881. Abbreviations: CFBP, Collection Française des Bactéries Phytopathogènes, Angers, France; NCIMB: National Collection of Industrial and Marine Bacteria, Aberdeen, UK.

\begin{tabular}{|c|c|c|c|c|c|c|c|c|c|}
\hline \multirow[t]{2}{*}{ Fatty acids* } & \multicolumn{9}{|c|}{ Species: } \\
\hline & 1 & $2 \dagger$ & 3 & 4 & 5 & 6 & 7 & 8 & 9 \\
\hline $10: 03-\mathrm{OH}$ & $1 \cdot 9(0 \cdot 1)$ & $2 \cdot 0(0 \cdot 2)$ & $3 \cdot 0(0 \cdot 1)$ & $3 \cdot 4(0 \cdot 2)$ & $3 \cdot 4(0 \cdot 3)$ & $3 \cdot 0(0 \cdot 2)$ & $2 \cdot 8(0 \cdot 1)$ & $2 \cdot 7(0 \cdot 1)$ & $3 \cdot 3(0 \cdot 3)$ \\
\hline $12: 0$ & $2 \cdot 5(0 \cdot 2)$ & $2 \cdot 8(0 \cdot 2)$ & $2 \cdot 2(0 \cdot 0)$ & $2 \cdot 6(0 \cdot 4)$ & $2 \cdot 3(0 \cdot 1)$ & $2 \cdot 3(0 \cdot 1)$ & $2 \cdot 8(0 \cdot 1)$ & $2 \cdot 8(0 \cdot 1)$ & $2 \cdot 8(0 \cdot 1)$ \\
\hline $14: 0$ & $1 \cdot 8(0 \cdot 2)$ & $3 \cdot 0(0 \cdot 1)$ & $2 \cdot 0(0 \cdot 1)$ & $2 \cdot 4(0 \cdot 3)$ & $1 \cdot 8(0 \cdot 1)$ & $1 \cdot 6(0 \cdot 2)$ & $3 \cdot 4(0 \cdot 2)$ & $2 \cdot 9(0 \cdot 1)$ & $3 \cdot 5(0 \cdot 1)$ \\
\hline $15: 1$ & $2 \cdot 0(0 \cdot 8)$ & $0 \cdot 0(0 \cdot 0)$ & $0 \cdot 0(0 \cdot 0)$ & $0 \cdot 0(0 \cdot 0)$ & $0 \cdot 0(0 \cdot 0)$ & $2 \cdot 6(1 \cdot 1)$ & $0 \cdot 0(0 \cdot 0)$ & $0 \cdot 9(0 \cdot 2)$ & $0 \cdot 0(0 \cdot 0)$ \\
\hline $15: 0$ & $11 \cdot 1(2 \cdot 2)$ & $1 \cdot 9(0 \cdot 3)$ & $0 \cdot 4(0 \cdot 1)$ & $0 \cdot 1(0 \cdot 1)$ & $0 \cdot 6(0 \cdot 1)$ & $6 \cdot 7(2 \cdot 2)$ & $0 \cdot 3(0 \cdot 2)$ & $2 \cdot 0(0 \cdot 1)$ & $0 \cdot 4(0 \cdot 2)$ \\
\hline $16: 1$ & $37 \cdot 8(1 \cdot 6)$ & $42 \cdot 7(0 \cdot 8)$ & $41 \cdot 0(1 \cdot 0)$ & $42 \cdot 9(3 \cdot 2)$ & $40 \cdot 8(0 \cdot 6)$ & $40 \cdot 7(1 \cdot 6)$ & $39 \cdot 5(0 \cdot 4)$ & $43 \cdot 3(0 \cdot 2)$ & $42 \cdot 8(0 \cdot 7)$ \\
\hline $16: 0$ & $22 \cdot 6(2 \cdot 8)$ & $28 \cdot 2(1 \cdot 6)$ & $33 \cdot 1(0 \cdot 2)$ & $32 \cdot 2(2 \cdot 1)$ & $35 \cdot 2(0 \cdot 6)$ & $33 \cdot 7(2 \cdot 3)$ & $27 \cdot 4(1 \cdot 6)$ & $28 \cdot 1(0 \cdot 1)$ & $31 \cdot 1(0 \cdot 9)$ \\
\hline 17:0cyclo & $0 \cdot 0(0 \cdot 0)$ & $0 \cdot 0(0 \cdot 0)$ & $0 \cdot 7(0 \cdot 1)$ & $0 \cdot 2(0 \cdot 3)$ & $0 \cdot 5(0 \cdot 7)$ & $0 \cdot 0(0 \cdot 0)$ & $0 \cdot 0(0 \cdot 0)$ & $1 \cdot 1(0 \cdot 1)$ & $0 \cdot 0(0 \cdot 0)$ \\
\hline $17: 0$ & $4 \cdot 8(1 \cdot 0)$ & $0 \cdot 8(0 \cdot 2)$ & $0 \cdot 1(0 \cdot 2)$ & $0 \cdot 0(0 \cdot 1)$ & $0 \cdot 3(0 \cdot 2)$ & $1 \cdot 6(0 \cdot 3)$ & $0 \cdot 1(0 \cdot 1)$ & $1 \cdot 2(0 \cdot 2)$ & $0 \cdot 2(0 \cdot 2)$ \\
\hline $18: 1 c i s 11$ & $12 \cdot 7(1 \cdot 3)$ & $18 \cdot 4(1 \cdot 8)$ & $15 \cdot 5(0 \cdot 7)$ & $15 \cdot 7(1 \cdot 7)$ & $14 \cdot 5(1 \cdot 0)$ & $7 \cdot 6(0 \cdot 3)$ & $23 \cdot 4(1 \cdot 0)$ & $15 \cdot 1(0 \cdot 2)$ & $15 \cdot 6(0 \cdot 5)$ \\
\hline $18: 0$ & $0 \cdot 2(0 \cdot 3)$ & $0 \cdot 1(0 \cdot 1)$ & $0 \cdot 4(0 \cdot 0)$ & $0 \cdot 3(0 \cdot 1)$ & $0 \cdot 1(0 \cdot 1)$ & $0 \cdot 0(0 \cdot 1)$ & $0 \cdot 1(0 \cdot 2)$ & $0 \cdot 0(0 \cdot 0)$ & $0 \cdot 0(0 \cdot 1)$ \\
\hline
\end{tabular}

* Fatty acids are listed using standard abbreviations (no. carbon atoms: no. double bonds). Each strain was extracted and analysed six times and data represent the mean value (standard deviation).

$\dagger$ Raw fatty acid data collected from CFBP 3231, 3240, 3245, 3248, 3251, 3252 and 3282.

A. facilis. The bootstrap value of this clustering was significantly high: $95.4 \%$ with the parsimony method, $76 \%$ with the neighbour-joining method (partial sequences) and the branch was significantly positive at $P<0.01 \%$ in the maximum-likelihood analysis.

Similarity values were calculated for the closest relatives to the new Acidovorax species. The level of similarity value (approx. 92\% with $A$. facilis) would indicate that this organism is a new species (Stackebrandt \& Goebel, 1994).

\section{Fatty acid analysis}

Analysis of quantitative fatty acid data are presented in the form of a dendrogram (Fig. 3). All of the anthurium isolates cluster with reference strains from the family Comamonadaceae, and are clearly separated from species of the families Burkholderiaceae and Pseudomonadaceae. Closer inspection reveals that CFBP $3232^{\mathrm{T}}$ is distinct from other $A$. anthurii strains.

The fatty acid data for all species of the genus Acidovorax studied here are shown in Table 5. Profiles were highly reproducible and the standard deviation was rarely more than $10 \%$ of the mean value. Qualitatively the profiles were very similar, with large amounts of hexadecanoic (16:0) and hexadecenoic (16:1) acids found in all strains. In addition, 3hydroxydecanoic acid (10:0 3-OH) was the only hydroxylated fatty acid present in all the members of the genus Acidovorax studied here. CFBP $3232^{\mathrm{T}}$ was found to have a slightly different fatty acid profile from other anthurium isolates with significant amounts of pentadecanoic (15:0) and pentadecenoic (15:1) acids.

\section{DISCUSSION}

Twenty-nine strains isolated from bacterial leaf-spot of anthurium were compared with 42 strains including phytopathogenic type strains belonging to the genera Acidovorax, Burkholderia, Ralstonia and Pseudomonas. The analysis by numerical taxonomic methods of the 167 physiological and biochemical characteristics, summarized in a dendrogram demonstrated that 25 out of 29 strains pathogenic for anthurium, fell into phenon 1 defined at the distance $0 \cdot 39$. The closest relative belonging to phenons 2 and 3 corresponded to strains of a new Acidovorax sp. isolated from lambs' lettuce (distance level 0.45) and strains of $A$. avenae subsp. avenae and $A$. avenae subsp. cattleyae (distance level 0.48 ), respectively. On the basis of these phenotypic characteristics strains isolated from anthurium can be easily identified.

DNA-DNA hybridization results confirmed the findings of phenotypic analysis, since nine strains from phenon 1 showed a high level of mean relative binding with strain CFBP $3232^{\mathrm{T}}(89 \cdot 7 \mathrm{SD} 7 \cdot 2)$. One strain CFBP 3239 representative of phenon 6, isolated from anthurium but not pathogenic on this host, showed very low hybridization with CFBP $3232^{\mathrm{T}}$. Five reference strains of $A$. avenae (subsp. avenae, subsp. cattleyae, subsp. citrulli) and A. konjaci, showed low levels of relatedness ranging from 27 to $44 \%$ to members of phenon 1. A. facilis, A. delafieldii and $A$. 
temperans were not included because they belong to another rRNA branch (Fig. 2). All the other strains including those belonging to the genera Burkholderia, Ralstonia and Pseudomonas exhibited levels of hybridization below $8 \%$.

The $\mathrm{G}+\mathrm{C}$ value of strain CFBP 3240 was $66 \cdot 2 \mathrm{~mol} \%$ compared to $57 \cdot 4-70 \cdot 8 \mathrm{~mol} \%$ for strains of $A$. avenae subsp. avenae and $A$. avenae subsp. cattleyae (Willems et al., 1992). Therefore the $\mathrm{G}+\mathrm{C}$ ratio of this new bacterium is within the range of the genus Acidovorax. The results from our DNA studies clearly indicate that the strains isolated from anthurium constitute a homogeneous new species under the species definition of Wayne et al. (1987).

By rRNA-DNA hybridization this new species can be assigned to the $\beta$ subclass sensu Stackebrandt et al. (1988), and to rRNA superfamily III sensu De Ley (1978), more specifically the Comamonadaceae family and the genus Acidovorax. It belongs in the $A$. avenae-A. konjaci sub-branch. Despite the lack of complete $16 \mathrm{~S}$ rRNA sequences in databases the phylogenetic trees obtained agree with this result.

Comparison of the fatty acid data reveal the presence of 3-hydroxydecanoic acid as the sole hydroxylated fatty acid present in all anthurium isolates (Table 5), which is typical of members of the genus Acidovorax in particular (Oyaizu \& Komagata, 1983; Willems et al., 1990; Stead, 1992). Examination of the raw data from this study has shown that the presence or absence of pentadecenoic acid $(15: 1)$ is the major qualitative difference between CFBP $3232^{\mathrm{T}}$ and other $A$. anthurii. Differences in the fatty acid profiles of strains of the same species have been recorded previously, Stead (1992) found that Burkholderia (Pseudomonas) glumae comprised two distinct populations, similarly in a previous study of $A$. anthurii strains isolated from diseased anthuriums from Trinidad, isolates were recovered in two distinct clusters (Saddler et al., 1995).

Thus all our results are in favour of the description of a new species and we propose the name Acidovorax anthurii. The description below is based on the results presented above, as well as on those obtained by Prior \& Rott (1989).

\section{Description of Acidovorax anthurii sp. nov.}

Acidovorax anthurii (an.thu.rii. L. fem. n. Anthurium anthurium; L. gen. n. anthurii of anthurium, referring to the plant from which this phytopathogenic bacterium was first isolated).

On YBGA, colonies are circular, raised with an entire margin and white-creamy and brown diffusible pigment is produced. Cells are Gram-negative, straight rods, $0 \cdot 2-0.7 \times 1 \cdot 0-5.0 \mu \mathrm{m}$, motile by a long polar flagellum. Oxidase, catalase and urease are positive. Strictly aerobic, poly- $\beta$-hydroxybutyrate is accumulated in the cell, arginine is used as sole source of carbon. $\mathrm{H}_{2} \mathrm{~S}$ is produced from cysteine and cellulose is hydrolysed. Indole, levane and acetoin are not produced. Casein and aesculin are not hydrolysed. Acid is produced from galactose, arabinose and glycerol. Acetate, formiate, glycerol, DL-5-aminobutyrate, $\mathrm{D}(-)$ tartrate and azelate are utilized. Trehalose, caprylate, D-ribose, D-glucose, $N$-acetylglucosamine, L-arginine, saccharose, inositol, sarcosine, itaconate, D-xylose, L-tryptophan, aesculin and mannitol are not utilized. The sole hydroxylated fatty acid present is 3-hydroxy-decanoic acid. The $\mathrm{G}+\mathrm{C}$ content of the strain CFBP $3232^{\mathrm{T}}$ determined by thermal denaturation method is $63.5 \mathrm{~mol} \%$. All strains elicit a hypersensitive reaction on tobacco leaves (HR) and are pathogenic on anthurium, producing typical leaf-spot symptoms. The type strain has been deposited in the CFBP, Angers, France, as CFBP $3232^{\mathrm{T}}$.

\section{ACKNOWLEDGEMENTS}

We thank S. Belouin for technical assistance and A. Huard for designing the dendrograms.

\section{REFERENCES}

Ayers, S. H., Rupp, P. \& Johnson, W. T. (1919). A study of alkaliforming bacteria in milk. USDA Bulletin no. 782. Washington, DC: USDA.

Blakesley, R. W. (1993). Cycle sequencing. In DNA Sequencing Protocols (Methods in Molecular Biology series, vol. 23), pp. 209-218. Edited by A. M. Griffin \& H. G. Griffin. Totowa, NJ : Humana Press.

Brenner, D. J., McWorter, A. C., Leete Knutson, J. K. \& Steigerwalt, A. G. (1982). Escherichia vulneris: a new species of Enterobacteriaceae associated with human wounds. J Clin Microbiol 15, 1133-1140.

Brosius, J., Palmer, M. L., Kennedy, P. J. \& Noller, H. F. (1978). Complete nucleotide sequence of $16 \mathrm{~S}$ ribosomal RNA gene from Escherichia coli. Proc Natl Acad Sci 75, 4801-4805.

Chase, A. R. (1987). Compendium of Ornamental Foliage Plant Diseases. St Paul, MN: American Phytopathological Society.

Crosa, J. M., Brenner, D. J. \& Falkow, S. (1973). Use of a singlestranded-specific nuclease for analysis of bacterial and plasmid deoxynucleic acid homo- and heteroduplex. J Bacteriol 115, 904-911.

Dauga, C., Gillis, M., Vandamme, P., Ageron, E., Grimont, F., Kersters, K., De Mahenge, C., Peloux, Y. \& Grimont, P. A. D. (1993). Balneatrix alpica gen. nov., sp. nov., a bacterium associated with pneumonia and meningitis in a spa therapy centre. Res Microbiol 144, 35-46.

De Ley, J. (1978). Modern molecular method in bacterial taxonomy: evaluation application prospects. In Proceedings of the 4th International Conference of Plant Pathogenic Bacteria, vol. 1, pp. 347-357. Tours: Gilbert.

De Ley, J. \& De Smedt, J. (1975). Improvements of the membrane filter method for DNA:rRNA hybridization. Antonie Leeuwenhoek J Microbiol Serol 41, 287-307.

Descamps, P. \& Véron, M. (1981). Une méthode de choix des caractères d'identification basée sur le théorème de Bayes et la mesure de l'information. Ann Inst Pasteur/Microbiol 132 B, 157-170.

De Vos, P., Goor, M., Gillis, M. \& De Ley, J. (1985). Ribosomal ribonucleic acid cistron similarities of phytopathogenic Pseudomonas species. Int J Syst Bacteriol 35, 169-184. 
Dilbar, A. (1992). Studies on a new bacterial disease and other diseases of anthurium in Trinidad. MSc thesis, University of West Indies, St Augustin.

Felsenstein, J. (1981). Evolutionary trees from DNA sequences: A maximum likelihood approach. $J$ Mol Evol 17, 368-376.

Felsenstein, J. (1989). PHYLIP - phylogeny inference package (version 3.2). Cladistics 5, 164-166.

Hildebrand, D. C. (1971). Pectate and pectine gels for differentiation of Pseudomonas sp. and other bacterial plant pathogens. Phytopathology 61, 1430-1436.

Hugh, R. \& Leifson, E. (1953). The taxonomic significance of fermentative versus oxidative metabolism of carbohydrates by various Gram-negative bacteria. J Bacteriol 66, 24-26.

Kersters, K., Ludwig, W., Vancanneyt, M., De Vos, P., Gillis, M. \& Schleifer, K. H. (1996). Recent changes in the classification of the pseudomonads: an overview. Syst Appl Microbiol 19, 465-477.

Kimura, M. (1980). A simple method for estimating evolutionary rates of base substitutions through comparative studies of nucleotide sequences. J Mol Evol 16, 111-120.

Leliott, R. A., Billing, E. \& Hayward, A. C. (1966). A determinative scheme for the fluorescent plant pathogenic pseudomonads. J Appl Bacteriol 29, 470-489.

Maidak, B. L., Olsen, G. J., Larsen, N., Overbeek, R., McCaughey, M. J. \& Woese, C. R. (1997). The ribosomal database project. Nucleic Acids Res 25, 109-111.

Marmur, J. \& Doty, P. (1962). Determination of the base composition of deoxyribonucleic acid from its thermal denaturation temperature. J Mol Biol 5, 109-118.

Miller, L. T. \& Berger, T. (1985). Bacteria identification by gas chromatography of whole cell fatty acids. Hewlett-Packard Application Note 228-241.

Natural, M. P. (1990). Anthurium blight in the Philippines. In Proceedings of the Third Anthurium Blight Conference, p. 38. Edited by A. M. Alvarez. Hawaii: Hawaii Institute of Tropical Agriculture and Human Resources.

Nishijima, W., Oyadomari, A., Uchida, J. Y. \& Aragaki, M. (1980). Bacterial blight of Anthurium. Instant Information. Manoa: University of Hawaii.

Olsen, G. J., Matsuda, H., Hagstrom, R. \& Overbeek, R. (1994). A tool for construction of phylogenetic trees of DNA sequences using maximum likelihood. CABIOS 10, 41-48.

Ostle, A. \& Holz, J. G. (1975). Nile Blue A as a fluorescent stain for poly- $\beta$-hydroxybutyrate. Appl Environ Microbiol 44, $238-240$.

Owen, R. J. \& Lapage, S. P. (1976). The thermal denaturation of partly purified bacterial deoxyribonucleic acid and its taxonomic implications. J Appl Bacteriol 41, 335-340.

Oyaizu, H. \& Komagata, K. (1983). Grouping of Pseudomonas species on the basis of cellular fatty acid composition and the quinone system with special reference to the existence of 3hydroxy fatty acids. J Gen Appl Microbiol 29, 17-40.

Prior, P. \& Rott, P. (1989). Bacterial leaf spot of Anthurium caused by a Pseudomonas sp. in the French West Indies. $J$ Phytopathol 124, 215-224.

Prunier, J. P. \& Kaiser, P. (1964). Etude de l'activité pectinolytique chez des bactéries phytopathogènes et saprophytes des plantes.
I. Recherche des enzymes pectinolytiques. Ann Epiphyt (Paris) 15, 205-209.

Rhodes, M. E. (1958). The cytology of Pseudomonas spp. as revealed by a silver-plating staining method. J Gen Microbiol 18, 639-648.

Rott, P. \& Prior, P. (1987). Un dépérissement bactérien de l'anthurium provoqué par Xanthomonas campestris pv. dieffenbachiae aux Antilles francaises. Agron Trop 42, 61-68.

Saddler, G. S., O'Grady, E. B. \& Spence, J. A. (1995). Characterization of a pseudomonad-like bacterium pathogenic for Anthurium species. Bull OEPP 25, 211-217.

Saitou, N. \& Nei, M. (1987). The neighbor-joining method: a new method for reconstructing phylogenetic trees. Mol Biol Evol 4, 406-425.

Sasser, M. (1990). Identification of bacteria through fatty acid analysis. In Methods in Phytobacteriology, pp. 199-213. Edited by Z. Klement, K. Rudolph \& D. C. Sands. Budapest: Akadémiai Kiadó.

Sneath, P. H. A. \& Sokal, R. R. (1973). Numerical Taxonomy: the Principles and Practice of Numerical Classification. San Francisco: Freeman.

Stackebrandt, E. \& Goebel, B. M. (1994). Taxonomic note: a place for DNA-DNA reassociation and 16S rRNA sequence analysis in the present species definition in bacteriology. Int $J$ Syst Bacteriol 44, 846-849.

Stackebrandt, E., Murray, R. G. E. \& Trüper, H. G. (1988). Proteobacteria classis nov., a name for the phylogenetic taxon that includes the "purple bacteria and their relatives". Int J Syst Bacteriol 38, 321-325.

Stead, D. E. (1992). Grouping of plant-pathogenic and some other Pseudomonas spp. by using cellular fatty acid profiles. Int J Syst Bacteriol 42, 281-295.

Swofford, D. (1990). PAUP: phylogenetic analysis using parsimony, version 3.0. Computer program distributed by the Illinois Natural History Survey, Champaign, IL, USA.

Van de Peer, Y., Van den Broeck, I., De Rijk, P. \& De Wachter, R. (1994). Database on the structure of small ribosomal subunit RNA. Nucleic Acids Res 22, 3488-3494.

Wayne, L. G., Brenner, D. J., Colwell, R. R. \& 9 other authors (1987). International Committee on Systematic Bacteriology. Report of the ad hoc committee on reconciliation of approaches to bacterial systematics. Int J Syst Bacteriol 37, 463-464.

Willems, A., Falsen, E., Pot, B., Jantzen, E., Hoste, B., Vandamme, P., Gillis, M., Kersters, K. \& De Ley, J. (1990). Acidovorax, a new genus for Pseudomonas facilis, Pseudomonas delafieldii, E. Falsen (EF) group 13, EF group 16, and several clinical isolates, with the species Acidovorax facilis comb. nov., Acidovorax delafieldii comb. nov., and Acidovorax temperans sp. nov. Int $J$ Syst Bacteriol 40, 384-398.

Willems, A., Goor, M., Thielemans, S., Gillis, M., Kersters, K. \& De Ley, J. (1992). Transfer of several phytopathogenic Pseudomonas species to Acidovorax as Acidovorax avenae subsp. avenae subsp. nov., comb. nov., Acidovorax avenae subsp. citrulli, Acidovorax avenae subsp. cattleyae, and Acidovorax konjaci. Int J Syst Bacteriol 42, 107-119.

Woese, C. R. (1987). Bacterial evolution. Microbiol Rev 51, 221-271.

Young, F. (1990). Farm assessment of bacterial blight disease on Anthurium in Jamaica. Proc Interam Soc Trop Hort 34, 11-17. 